\title{
From Scientism to Humanism - the Influence of Modern Western Cultural and Ideological Thoughts on Lu Xun
}

\author{
Wei Chenlin \\ School of Humanities \& Social Sciences, \\ Xi'an Jiaotong University, China.
}

\begin{abstract}
Lu Xun's shift from "saving the nation through science" to "saving the nation through literature" was an important watershed in modern China's process of learning from the West, as well as in Lu Xun's personal transition from Scientism to Humanism. As interpenetrating and intertwining aspects of modern Western culture, Scientism and Humanism are at the same time mutually different and mutually interrelated. In the past, most researchers have focused on the differences between these two cultural thoughts and neglected their connections. But actually, precisely because they are connected and interrelated to each other, Lu Xun actively kept up with the latest philosophical and cultural trends in the West at the same time he was introducing the scientific achievements of the West; this is also why Lu Xun first taught science after returning to China, then switched to teaching literature after the May Fourth Movement.He also urged people who were engaged in literature to also read scientific books. Only by realizing the differences between the two and paying attention to their connections can we better understand Lu Xun's cultural choice between Scientism and Humanism.
\end{abstract}

\section{INTRODUCTION}

During his stay in Japan, Lu Xun discovered that after the time of Hegel's classical philosophy, Western modern philosophy had diverged into the two extremes of Science and Humanism:

"The ideal lies in the mutual coordination of the individual's knowledge and sentiment. Take the knowledge-based faction as an example, they are wise and resourceful, they can transfer the objective world to their subjective world. This kind of idea reached the acme when Hegel appeared......By the end of the nineteenth century, the ideal had changed. The wise and sagacious people had a deep degree of internal reflection. Therefore, those who have the ability to coordinate (intellectual and emotional) as imagined by the ancients will never appear today; only the superior willpower can be hoped for. Being able to face the real world emotionally, these brave and fighting talents, can still become stronger even have repeatedly fallen to the ground, as well as finally realize their ideals_- the meaning of inner personality lies here." (Lu Xun 2005:1:55-56)往所理想, 在知见情操, 两皆调整, 若主智一派, 则在聪明睿智, 能 移客观之大世界于主观之中者。如是思惟, 迨黑该尔 (F.Hegel) 出而达其极顾至 
Chenlin, W. (2020). From Scientism to Humanism - the Influence of Modern Western Cultural and Ideological Thoughts on Lu Xun. Advances in Social Science. Research Journal, 7(5) 41-53.

\section{十九世纪垂终, 则理想为之一变, 明哲之土, 反省于内面者深, 因以知古人所设具 足协调之人, 决不能得之今世; 惟有意力轶众, 所当希求, 能于情意一端, 处现实 之世, 而有勇猛奋斗之才, 虽屡踣屡僵, 终得现其理想: 其为人格, 如是焉耳。}

But he has also understood the unity of these "two cultural trends":

"Nietzsche, on the other hand, stimulated by Darwin's theories of evolution, attacked Christianity and created an entirely different philosophy, that of the Superman (Übermensch, Chinesechaoren超人). The proposals of Hegel and Nietzsche, though based on science, were still tainted with distinctly religious and fantastical elements." (Lu Xun 2005:8:31) 至尼佉氏, 则刺取达尔文进化之说, 掊击景教, 别说超人。虽 云据科学为根, 而宗教与幻想之臭味不脱。

This shows the difference and connection between Scientism and Humanism, which is very important for us to understand Lu Xun's thought during his stay in Japan.

However, up to now, no one in the Lu Xun study community has explored Lu Xun's cultural choice between Scientism and Humanism from the perspective of this modern cultural division and its connection. It is precisely because of this that some people cannot understand why Lu Xun, who was very familiar with modern science and its history, would oppose eradicating superstition, destroying idols, banning idolatrous processions (yingshensaihui迎神赛会), and sneering myths in Po E'shengLun破恶声论（Toward a Refutation of Malevolent Voices）. In fact, the latter belongs to the category of ethical values, an area beyond scientific propositions. This article will start with Lu Xun's acceptance of Western science and cultural thoughts, then analyze how Scientism and Humanism shape Lu Xun's ideological character.

\section{THE SHAPING OF LU XUN'S THOUGHT BY SCIENTISM}

Lu Xun's exploration of science and his strong interest in the history of science can be seen in many aspects. For example, he translated many works of science fiction; he also combed the history of Chinese science, from which he learned many cultural lessons as well as historical and comparative thinking methods; as another example, he also accepted the theory of evolution.

Specifically, when publishing Shuo Ri说鈤(On Germanium) and ZhongguoDizhiLuelun 中国地质略论 (Brief Outline of Chinese Geology), Lu Xun translated many science fiction works around 1903 such as YuejieLvxing 月界旅行(From the Earth to the Moon), Didi Lvxing地底旅行(Journey to the Center of the Earth), Zaoren Shu造人术(the Art of Creating Humanity), and BeijiTanxian Ji北极探险记 (Arctic Adventure). These works greatly expanded Lu Xun's concept of space-time, encouraged his macro-imagination of the world, and also to an extent changed his view of the world and nature, which had previously been shaped by the realities of thesubsistence-basedChinese rural economy.

Secondly, Lu Xun's interest in Western science is also reflected in his emphasis on scientific culture. He explored the reasons of scientific development and thereby learned the historical and comparative modes of thinking. In Lessons from the History of Science, Lu Xunsays: 
"When evaluating the history of an era, later generations always make different comments because of their different interpretive standpoints. If we judge things that happened in ancient times by current circumstances, we may feel unsatisfied when realizing the inconsistencies. But if we imagine that we are a person living in ancient times, exploring ancient people's mental state without reference to today's situation, we may find that the ancestors' practice was not wrong.” (Lu Xun 2005:2:26) 盖世之评 一时代历史者, 褒贬所加, 轧不一致, 以当时人文所现, 合之近今, 得其差池, 因 生不满。若自设为古之一人, 返其旧心, 不思近世, 平意求索, 与之批评, 则所论 始云不妄。

He argues that we should not judge the ancients with modern ideas, but examine them in their historical context. "The ancients cannot be faulted for what they did not know." (Lu Xun 2005:2:26) 古所未知, 后无可愧。This historical attitude determines the focus point of Lu Xun's antitraditional actions after the May Fourth Movement was not criticize the ancients, but to remodel the national character of his contemporaries. However, merely learning the historical way of thinking is not sufficient to evaluate the characteristics of an era or a culture. Therefore in Lessons from the History of Science, we can see that Lu Xun has also absorbed the comparative method:

"If we discuss the practices of the ancients, how do we decide whether to appreciate or depreciate? It is necessary for us to refer the practices of people from other countries when they experience similar sufferings, and reach the correct conclusion through comparison." (Lu Xun 2005:2:26) 盖凡论往古人文, 加之轩轾, 必取他种人与是相当 之时劫, 相度其所能至而较量之, 决论之出, 期近正耳。

This kind of comparative methodology had a direct impact on Lu Xun. Therefore, when he analyzes Chinese culture and national character, he uses Western culture as the reference system. This can be seen from his works. For example, in On the Power of Mara Poetry, Lu Xun introduced not only Byron, Shelley, Pushkin, Adam Mickiewicz, Petofi from a comparative viewpoint, but also took Byron as the reference frame (in that Lu Xun thought Byron seeks independent freedom and fights against challenge without hesitation) and argued that Qu Yuan屈原 lacked rebellious spirit and independent personality. To give another example, Lu Xun also uses the comparative method in Lessons from the History of Science to explore the influence of Indian religion and literature on the history of the Chinese fiction.(Sun Changxi: 1982:6:10)

Furthermore, the theory of evolution also had a significant influence on Lu Xun. In the article Ren zhilishi人之历史 [The History (of the evolution) of Humankind], Lu Xun introduced the historical development of biological evolution from Linnaeus, Lamarck, Cuvier, Goethe, Wallace, to Darwin and Haeckel. However, from Lu Xun's emphasis of "human history" explored by Haeckel, we can realize that he pays more attention to the development of human civilization Therefore, Lu Xun introduced the theory of evolution into the field of humanities and social sciences, and used it to comprehend and evaluate Chinese culture, and then formed a kind of cultural view that opposes tradition-C - Originally, nature as conceived by Chinese Daoists is static, with human beings and allthe other living things harmoniously coexisting; whereas nature as depicted by Darwin is dynamic, full of conflict and fighting, summarized as "the superior is selected, the inferior is eliminated, the fittest survives." 
Chenlin, W. (2020). From Scientism to Humanism - the Influence of Modern Western Cultural and Ideological Thoughts on Lu Xun. Advances in Social Science. Research Journal, 7(5) 41-53.

Specifically, Lu Xun analogizes this cruel and ruthless competition law to human society. He believes that if individuals are not aggressive or competitive, they will be weeded out by others; if the nation is not competitive or self-strengthening, it cannot survive in the world. In this way, the evolution theory not only prompted Lu Xun towards struggle and self-improvement, but also gave him a tragic sense of national crisis, "Although so many are born, they will be wiped out by the real men, just like wolves killed by the hunters!” (Lu Xun 2005:1:453)即使生得多, 也会给真的人除灭了, 同猎人打 完狼子一样! In addition, the emphasis on inheritance, which constitutes part of the evolution theory, also inspired Lu Xun to associate individual inheritance with the inheritance of national bad habits, making him realize the difficulty of remodeling national character. Therefore, he said that "the fatuous ancestors raising the muddled descendants, this is the principle of inheritance."(Lu Xun 2005:1:329) 昏乱的祖先, 养出昏乱的子孙, 正是遗传的定理。

"The impression of the grandmother indicates the future impression of the baby. Therefore, if someone wants to predict his wife's character in the future, he only needs to look at his mother-in-law.” (Lu Xun 2005:3:149) 祖母的模样, 就预示着那娃儿的将 来。所以倘有人要预知令夫人后日的丰姿, 也只要看丈母。Therefore, the inferior trait of today's national characteristic is caused by bad genetics - "the things that help the fatuous (the documents of Confucianism and Daoism)” 助成昏乱的物事 (儒道两派 的文书)，and “once the national characters are created, no matter how good or bad they are, it is no more easy to change.”(Lu Xun 2005:1:329) 民族根性造成之后，无论 好坏，改变都不容易的。

More than that, he also criticizes China's static and stagnant cultural traditions with the dynamic and changing culture brought about by the theory of evolution, this is also the reason why he highly praised Mara poets who “determine the resistance, hope the action” 立意在反抗, 旨归在动作. More importantly, when the law of nature depicted by the theory of evolution was applied to the observation of society by Lu Xun as a substantive methodology, it actually became Lu Xun's "glimmer of hope" when he was extremely depressed: he believed that with the evolution of society, the younger would turn out better than the elderly, the future would be better than the present, and that therefore he could look forward to a brighter future.

If free competition is one of the core traits of modern society, then Lu Xun's acceptance of evolution theory enabled him to acquire the modernity of his ideology, as well as paved the way for his intellectual development from modern times (1840-1919) to the contemporary age (1919-1949 ) . It is precisely because of accepting the theory of evolution and introducing it into the realm of social and humanities, that Lu Xunnaturally absorbed the theory of Nietzsche successfullyand later accepted Marxism-Leninism with its emphasis on class struggle.

It is worth noting that Lu Xunconsiders Nietzsche's "will to power" is a development of Darwinism, when Nietzsche himself thought that his doctrine had nothing to do with Darwin. Nietzsche believes that "struggling for survival" is seldom in the doctrine of survival competition: "Struggling for survival is only an exception, a will that is usually suppressed temporarily for life."( Nietzsche:1986:20) 为生存而挣扎仅仅是一种例外, 一种为了生活而暂时抑制的意志While the Superman will pursue his "will to power" even if lacking basic survival conditions. Moreover, the saying "select the superior, eliminate the inferior"is not feasible in Nietzsche's ideology system, 
"because the weak are the majority, and they are good at preserving themselves through patience, prudence, disguise, and deceitful; the strong are more likely to destroy when pursuing 'will to power' at the expense of life. " (Zhou, Guoping:1986:73)因为弱者是多数, 而且善于通过忍耐、审 慎、伪装、狡诈来保存自己; 强者为了追求强力却不惜牺牲生命，较容易毁灭。

But Lu Xun did not seem to notice this at that time. He believes that in the sense of emphasizing social competition, survival of the fittest, social Darwinism is related to Nietzsche's individualism and Superman doctrine. He even regards Darwin as a bridge to have a better comprehension of Nietzsch. After all, when Lu Xun introduced the theory of evolution from Western natural science into the field of humanities and social sciences, he transformed it with his own understanding, which we usually called "subjective narration." Or we can consider as that it is because of the "subjective narration" and "reasonable misunderstanding" of Darwin's evolution theory that Lu Xun approached to Nietzscheism-After all, evolution theory is only a science that explores nature and biology instead of a teleology or axiology.-Even so, Lu Xun did not carry through this "reasonable misunderstanding", otherwise he would affirm the rationality of imperialist invasion, which is exactly what Lu Xun tried to oppose with Tolstoy's humanitarianism. This part of the content will be discussed later.

We can also see the influence of evolution theory on Lu Xun's work. For example, with a large number of scientific facts, Ernst Haeckel demonstrated the similarity between the evolution of human race and individual growth. Lu Xun accepts Haeckel's theory of evolution and realizes that from the part one could see the whole, from the individual one could infer the race. This idea sheds light on many of Lu Xun's works: Lu Xun creates the character "Ah Q" when analyzing Chinese national character; investigates the harm of the slavery-style destruction to China in the discussion of the fall of the Leifeng Pagoda; raises the idea of Chinese people's “Ten Sights Disease” 十景病 when examining people's regret that one of the ten historic sights of the West Lake had been destroyed; argues the anesthesia of the rulers when seeing sphecidae; and discusses the "Han and Tang spirit" 汉唐精神from the examination of a bronze mirror. Lu Xun's admiration of the evolution theory can also be seen in his appeal-"save the children" in the "A Madman's Diary", which contradicts the Chinese traditional virtue of giving priority of respect and care to the elderly over the children.

From the above we can see the influence of Western scientific and scientific thinking methods on Lu Xun and his literary creation. It should be pointed out that LuXun's interest in Western science stems from the strong practical needs of saving the country by science. Therefore, whether it is the end of Brief outline of Chinese geology or the end of Lessons from the History of Science his foothold of introducing science is patriotic. However, as Lu Xun gradually discovered that the way of learning advanced Western technology is in vain, he decisively chose the pen instead of the scalpel, as well as introduced Western culture and literature instead of science-This is also why he felt it urgent to connect Darwinism with Nietzsche subjectively at that time. Next, this article will introduce the influence of Western modern humanistic thoughts on Lu Xun's cultural criticism and his literary career, as well as the inevitability of Lu Xun's shift from Scientism to Humanism. 


\section{THE INFLUENCE OF WESTERN MODERN HUMANISM ON LU XUN}

The influence of Western modern humanistic thought on Lu Xun and on the whole Chinese modern culture and literature via Lu Xun can be seen from the thought paradigm that Jaroslav Prusek established for the first 20 years of modern Chinese literature. Prushek says: "Subjectivism, individualism and pessimism, as well as the feelings of life tragedy, combined with the demands of resistance, and even the tendency of self-destruction, are the most prominent feature of Chinese literature from the May Fourth Movement in 1919 until the outbreak of the Anti-Japanese War."(Průšek 1987:4) "In a society fettered by tradition, the desire of personal self-determination is weakened by the needs and claims of religion and traditional morality, and even completely suffocated... a modern, free, self-determining personality, undoubtedly cannot be born before the smashing of the traditional concepts, as well as the elimination of the entire social structure. Therefore, China's modern revolution-first and foremost is an ideological revolution-one in which individuals fight against traditional dogmas with individualism. In this sense, we can truly understand the incomparable importance of subjectivism and individualism in modern China's thought and art."(Průšek 1987:2)This kind of "subjectivism and individualism", as early as 1907, (before the May Fourth movement), was strongly advocated by Lu Xun, "driven by rebellion and destruction to build a new hope of rebirth. It targets the old culture in all its forms."(Lu Xun 2005:1:50) （以反动破坏充其精神, 以获新生为其希望, 专向旧有之文明, 而加之掊击扫荡焉） This anti-tradition and anti-mediocre proposition, which pits "individual arrogance" against "combinational arrogance", manifested in On the Aberrant Development of Culture, that is "uphold individual intelligence instead of material wealth, and assert individuality rather than popular opinion." (Lu Xun 2005:1:47) (掊物质而张灵明, 任个人而排众数)

Lu Xun's understanding of the development of modern Western civilization in the 19th century can be seen in On the Aberrant Development of Culture. He believed that Western culture in the 19th century had two major characteristics: one is the emphasis on the material, and the other is the admiration for democracy: "It is exactly one of the political tides of the nineteenth century that if most of the others think something is right, the one who follows the "right" of the majority will himself be "right", while a person who claims "his or her own right" different from others' "right" will be wrong. Governing the country according to the opinions of the majority signifies an authoritarian rule for the minorities with different opinions. This "tyranny of the majority" is one of the nineteenth century's political tides, and has continued all the way to the present with no sign of ending. Another example is the admiration of the progress of material civilization.... As people enjoyed the benefits of material progress for a long time, their faith in it had been strengthened accordingly. Material civilization has gradually become the norm, it is seen as the foundation of all the objective existence, which people use to limit and summarize the whole spiritual world. (The above concept) becomes unshakable, and is highly praised by the public as the only as well as the highest standard in daily life, people only pay attention to pursue material progress, which is another tide of the 19th century, and it has endured all the way until now and we cannot see any sign of its end.( Lu Xun 2005:1:49) (同是者是, 独是者非, 以多数临天下而暴独特者, 实十九世 纪大潮之一派, 且曼衍入今而未有既者也。更举其他, 则物质文明之进步是已。……食其赐, 信乃弥坚, 渐而奉为圭臬, 视若一切存在之本根, 且将以之范围精神界所有事, 现实生活, 胶不 可以移, 惟此是尊, 惟此是尚, 此又十九世纪大潮之一派, 且曼衍入今而未有既者也。）Lu Xun refuted this 19th-century Western civilization, and his refutation, which was characterized by the 
development of democracy and materialism, were derived from the trend of Western modern Humanism at the end of the century.

First, let us take a look at why Lu Xun disapproves of democracy and materialism. The reason he opposes democracy is that it emphasizes "convergence" and "make the world consistent, without any difference between different people in society."( Lu Xun 2005:1:51) ( 使天下人人归于一致, 社会之内, 荡无高卑) In addition, "there are not many wise people in a mob"( Lu Xun 2005:1:52)( 人群之内，明哲非多)Therefore, this kind of democracy will inevitably generate a declining culture , not only "ignore the importance of individuality, and seek to eliminate the differences in people's personalities." (于个人特殊之性, 视之䒼如, 既不加之别分, 且欲致之灭绝) Such a practice "when occurs, will make those people who are originally committed to pure culture become narrowminded" (流弊所至, 将使文化之纯粹者, 精神益趋于固婳) and "the whole society becomes third-class"( Lu Xun 2005:1:52)（全体以沦于凡庸）in the end. It is also on this basis that Lu Xun, who was influenced by the humanistic trend at the end of the century, proposed to "give up the mediocre and hope for the excellent, instead of restraining the excellent and accommodating themediocre"( Lu Xun 2005:1:54)（与其抑英哲以就凡庸, 曷若置众人而希英哲) and even advocate "the right and wrong cannot be decided by the mediocre, they cannot guarantee an impartial result ingovernment affairs. The aim of governing the country properly will not be achieved if judgements are made by the mediocre. Only when the Superman appears, will the world be peaceful. If this is not the case, the excellent are required." (Lu Xun 2005:1:53) (是非不可公于众 , 公之则果不诚; 政事不可公于众, 公之则治不郅。惟超人出, 世乃太平。苟不能然, 则在英哲 。) Lu Xun's attitude to oppose democracy is quite determined. He also criticizes Western materialism, because he believes fetishism will dim "the light of the spirit"性灵之光, and finally result in "the accelerated destruction of China”(Lu Xun 2005:1:58) 中国之沉沦以益速:

"At the end of nineteenth century, the defects of excessive abuse of material became increasingly obviously, all the things became invariably materialized. The spirits became increasingly defective, while civilization ideas became mediocre. People only pursue the objective material world while abandoning the subjective inner spiritual world and don't do any self-examination. Paying attention to the external objective world while indulging the inner subjective world, urging for the material achievements while losing the essence of it, the public was veiled by their material desire, society became decadent and ceased to be polished. Therefore all the evil, which are hypocritical and cunning, took this opportunity to sprout, making the light of spirit getting darker the common problem of the other side of the 19th century civilization is roughly like that."(Lu Xun 2005:1:54) 递夫十九世纪后叶, 而其弊果益昭, 诸凡事物, 无不质化 , 灵明日以亏蚀, 旨趣流于平庸, 人惟客观之物质世界是趋, 而主观之内面精神, 乃舍置不之一省。重其外, 放其内, 取其质, 遗其神, 林林众生, 物欲来蔽, 社会 憔悴, 进步以停, 于是一切诈伪罪恶, 䒼弗乘之而萌, 使性灵之光, 愈益就于黯淡 :十九世纪文明一面之通弊, 盖如此矣。 
In Lu Xun's view, the literary trend of thought at the end of the century showed a corrective attitude-it is anti-democratic, and therefore highly praises individuality and calls for the Superman; it advocates the "non-material", and hence greatly publicizes subjectivism and voluntarism. Influenced by this philosophical trend, Lu Xun introducesseveral individualist philosophers in On the Aberrant Development of Culture: Steiner from Germany, who possess extremely individualism and acts as a pioneer in the world at that time (以极端个人主义现于世); Schopenhauer from Germany, who emphasis independence, carrying forward "the ego", and respecting the genius (愈益主我扬己而尊天才); Kierkegaard from Denmark, who takes the enlargement of national personality as the highest moral ideal; Ibsen from Norway, who is quite powerful and combative, has the tendency of being anti-social and anti-democracy...after depicting the development process of this will to power, he then elevates Nietzsche to the supremacy, in that he "resisted the society and the customs at the time strenuously, demonstrating the perfect development of individuality"(Lu Xun 2005:1:55) (力抗时俗, 示主观倾向之极致), and can be considered as an “outstanding figure of individualism” (Lu Xun 2005:1:53) (个人主义之至雄桀者).

Subjectivism and voluntarism, which opposed to non-materials, also had a great impact on Lu Xun. Lu Xun believes that the excessive abuse of material may strangle people's spiritual lives, "the contributions made by subjectivism and voluntarismare greater than that of a ship during a flood. (Lu Xun 2005:1:54)主观与意力主义之兴, 功有伟于洪水之有方舟". In On the Aberrant Development of Culture, Lu Xun introduced the characteristics of subjectivism: "the first one is to only take subjective thoughts as criterion, and apply it when considering things; the other is to value the subjective inner spiritual world more than the external objective material world."一谓惟以主观 为准则, 用律诸物; 一谓视主观之心灵界, 当较客观之物质界为尤尊.When going away from external objects, "keep to your own heart, we will feel self-confidence, as well as selfgratification.”(Lu Xun 2005:1:55)独来往于自心之天地, 确信在是, 满足亦在是.It is precisely because of this that Lu Xun highly praised the Mara poets: "both Nitzsche, Ibsen and others, on the basis of their belief, resisted the society and the customs of the time strenuously, demonstrating the ultimate development of individuality, when it arrives to Kierkegaard, he believes that all of the truth and criterion is subjective, subjectivity is truth." (Lu Xun 2005:1:55)尼佉伊勃生诸人, 皆据 其所信, 力抗时俗, 示主观倾向之极致, 而契开迦尔则谓真理准则, 独在主观, 惟主观性, 即为 真理.If subjectivism emphasizes an ego that is not restricted by any external object, voluntarism attaches this "ego" a "subjective fighting spirit": "Schopenhauer assert that when introspection is achieved, people may be suddenly enlightened, therefore he thought willpower is the ontology of the word; and the thing Nietzsche look forward to is the masterpiece of great power, as well as the Superman who resembles God. While the protagonists described by Ibsen are almost living on revolution, they are powerful and good at struggling, they are also the stronger who would never feel scared even if they went against the whole world.” (Lu Xun 2005:1:56)故如昮宾霍尔所张主， 则以内省诸己, 豁然贯通, 因曰意力为世界之本体也; 尼佉之所希冀, 则意力绝世, 几近神明之 超人也; 伊勃生之所描写，则以更革为生命，多力善斗，即迕万众不慑之强者也。

Under the influence of this philosophy, Lu Xun proposed to "uphold individual intelligence instead of material wealth, and assert individuality rather than popular opinion” 掊物质而张灵明，任个人 而排众数, against people's alienation of science and material, promote the value of the individual. Later on, he introspected on gregarious democratic culture strangling people's personalities, called 
for the appearance of a Nietzsche-like Superman with xinsheng 心声 (voice of the heart)and Neiyao 内曜(inner-brilliance), as well as the kind of strong subjective will. He hoped that through “respect the individuality and promote the spirit”尊个性而张精神, a fierce and overwhelming renguo人国(individual-based country) composed of conscious, independent, autonomous people could be established-"to survive in this world, as well as compete with other nations, we must first accomplish'individual independence', then realize 'national independence'; As for the methodological approach, we should respect each individual's personality and promote their spirit.” (Lu Xun 2005:1:58)故将生存两间, 角逐列国是务, 其首在立人, 人立而后凡事举; 若其道术, 乃必尊个性而张精神. In addition, Lu Xun also successfully foresaw the direction of Western civilization in the 20th century: "The new spirit of the twentieth century can almost certainly be built on the raging winds and furious waves, relying on the willpower of human beings to open up a path of life... The civilization of the twentieth century must be profound and solemn, its theme will be different from the civilization of the nineteenth century.”(Lu Xun 2005:1:56-57)二十世纪之新 精神, 殆将立狂风怒浪之间, 恃意力以辟生路者也……十世纪之文明, 必当沉遂庄严, 至与十 九世纪之文明异趣. In this way, Lu Xun, who is highly respected for personality liberation, has become a pioneer of the New Culture Movement.

This kind of western philosophical trend played an important role in Lu Xun's creative practice. For example, he twice translated the foreword of Thus Spoke Zarathustra, spoke highly of its quintessence that encourages human beings be positive and make progress. More than that, Nietzsche's will to power directly affects the Revenge (Fuchou复仇), Such a Warrior ( ZheyangdeZhanshi这样的战士），AFaint Blood Mark (DandandeXuehen淡淡的血痕) in Wild Grass (Yecao野草), (note that this influence is not limited to Lu Xun's ideas, but his artistic techniques and so on are also affected, such as the philosophical expression in Wild Grass, which reveals the depth of existence with symbols, metaphors, and hints, instead of abstract concepts or logical deduction, this writing method is same with Thus Spoke Zarathustra.) For another example, Nietzsche is desperate for "the public" in the society, deem that "All I have to look forward to are effective descendants" 聊可望者, 独苗裔耳.In the same, Lu Xun exclaims "save the children" at the end of The Madman's Diary. Furthermore, Lu Xun respected the kind of spirit expressed in Ibsen's An Enemy of the People (Renmin Gongdi人民公敌), which dare to fight against the majority and declare war on mediocrity, therefore the theme that use "individual arrogance" opposes "combinational arrogance" becomes the recurring culture in Lu Xun's early novels. In addition, Lu Xunhailed Ibsen as "the great man of pattern destruction" 轨道破坏的大人物,specifically creating "After Nora leaves her home" (NalaZouhouZenyang娜拉走后怎样) to discuss Ibsen's drama.In "Hot Wind (46)" he especially put forward that "rather than adore Confucius or Guan Yu, it is better to admire Darwin and Ibsen." (Lu Xun 2005:1:349)与其崇拜孔丘关羽, 还不如崇拜达尔文易卜生 .Take Ibsen as the new idol that can replace traditional culture...

Of course, Lu Xun's acceptance of modern humanistic thoughts has profound realistic reasons. If not becauseonly a few people in society were "awoken", and most of the population still "asleep" in the traditional illusions, Lu Xunwould not have accepted the trend of anti-democracy and sought individuality so actively. If even the numb spectators vote for the right and wrong, and the voting result is accepted, isn't this the nightmare of the awakened? In this way, after enriching and refining by the tide of promoting the individual's personality and inner-spirit, drawing onStirner, 
Chenlin, W. (2020). From Scientism to Humanism - the Influence of Modern Western Cultural and Ideological Thoughts on Lu Xun. Advances in Social Science. Research Journal, 7(5) 41-53.

Schopenhauer, Nietzsche, Kierkegaard, Ibsen, etc., Lu Xun's spirit shows obvious advancement and modernity.

\section{REASONS FOR LU XUN ACCEPTING AND TRANSFORMING WESTERN SCIENCE AND CULTURAL THOUGHTS}

We have already mentioned Lu Xun's "reasonable misunderstanding" of evolution theory. Darwin's theory of evolution is originally only a science that explores nature and biology, without teleology or anxiology. However, when Lu Xun introduced the theory of evolution to the social and humanities fields, he added his own understanding and transformed it on purpose. Specifically, on the basis of "only the fittest can survive the natural selection" and "eliminate the inferior", the theory of evolution, with the influence of the modern humanistic thoughts, is extended to an ethical theory that makes people strive for self-improvement in social competition, and especially emphasized Nietzsche's enlargement of "will to power". After all, when the Western powers were vying for the hegemony and revealed the intention to carve up China, if the Chinese people did not struggle for self-reliance, they would be "eliminated" by other powerful countries from the world.

However, it should be pointed out that although Lu Xun agrees with evolution theory and individualism, his acceptance is within limits. Because if he was to absolutely affirm the rationality of survival of the fittest and the elimination of the inferior, then he could not logically condemn imperialist aggression towards China, not to mention that Nietzsche praised war and believed the weak should make sacrifices for the powerful Superman. When facing the contradiction between evolution and Nietzsche, Lu Xun turned to Tolstoy and put forward the theory of "self-introspection" 反诸己. He advocated that we should be sympathetic and feel for others, emphasizing "conscience" and humanitarianism, "always abhorring bloodshed and slaughter, showing the greatest sorrow when taking leave of relatives or friends, and being content in their daily tasks, that is human nature"(Lu Xun 2005:8:35) 恶喋血, 恶杀人, 不忍别离, 安于劳作, 人之性则如是. In this way, the “Tolstoian-Nietzschean Theory” 托尼学说, an ideological paradigm that combines individualism and humanitarianism, was established in Lu Xun's mind. However, the inner-contradictions of this ideological paradigm are obvious: Nietzsche emphasizes the Will to Power and dislikes useless sympathy; Tolstoy emphasizes the simplicity of feelings and praises compassion. Nietzsche praised rigorous Spartan-style discipline and theindividual's instinct of fighting and conquering; on the contrary, Tolstoy advocated inaction which can "govern by non-interference" and opposed war many times in his works. Nietzsche considers that the mediocreis worth sacrificing for the birth of the Superman, while Tolstoy sympathizes with the misfortune of the inferiors ... Why did Lu Xun have such contradictions when accepting foreign thoughts? What criteria did he use to make a subjective choice when accepting Western ideas?

The author believes that Nationalism is the starting point and internal criterion for Lu Xun to accept Western thoughts and make cultural choices. It is precisely because Lu Xun takes national salvation as his historical mission, and clearly recognizes the practical needs of country-improvement and national salvation, that he finally makes tradeoffs between Western scientific and cultural thoughts, as well as carries out innovations based on this subjective purpose when accepting foreign trends.

This can be confirmed by the difference between Lu Xun and other Mara poets and modern philosophical-ideological trends. Ibsen and others are all aiming at the highness of the personality, 
for example, manifested in Nietzsche, the evolution of human beings and the emergence of a "Superman" is his ultimate purposes. while when it comes to Lu Xun, both "developing individuals" 任个人, "promoting the spirit" 张灵明and so on are only the means and tools, his fundamental and ultimate purpose is to rescue the Chinese nation. This echoes the expression in Wenhuapianzhilun 文化偏至论（Aberrant Development of Culture）: "If human beings can be self-conscious, people's individuality will be extended accordingly. The nation in a state of disunity can be transformed into a renguo人国(individual-based country) composed of conscious, independent, autonomous people. After the construction of renguo, we can be valiant and intrepid, stand erectly and independently in the word."(Lu Xun 2005:1:57) 国人之自觉至, 个性张, 沙聚之邦, 由是转为人国. 人国既建, 乃 始雄厉无前, 屹然独见于天下.It is precisely because of the cultural orientation of nationalism that Lu Xun's humanitarianism is not the same as that of Tolstoy. In a certain sense, Tolstoy is the result of Rousseau. However, Tolstoy in the eyes of Lu Xun is a philanthropist that maintained "no violence even to confront bad values"勿以暴力抗恶, against belligerence and tyrants' inaction: "If tyrants can be isolated on high by their vassals' and their servants' refusal to follow orders below, then all under heaven will be well governed.” (Lu Xun 2005:8:34)独夫孤立于上, 而臣仆不听命于下, 则 天下治矣.However, Lu Xun could not advocate that the Chinese not learn martial arts or not resist the aggression of imperialism violently, because "If one morning this had been actually put into effect throughout the Russian Empire, enemy troops would surely arrive to invade that same evening." (Lu Xun2005:8:34)载使全俄朝如是, 敌军则可以夕至. At this time, Lu Xun had to turn to Nietzschean theory, which seeks self-reliance and fights aggressively. The fact that Lu Xun can make the contradictory “Tolstoyism-Nietzschean Theory”托尼学说compatible with each other is the best certification for his ultimate purpose of saving the nation. He convinced that Nietzscheism is the key to the China's self-strengthening and Tolstoyism to anti-imperialism.

Therefore, it is easy to understand why Lu Xun praised Byron the most during his stay in Japan. He needed to achieve a balance between individualism and humanitarianism that could meet the needs of national development. Byron differs from Tolstoy in that he advocates individuality, revolt and revenge, glowering at slavish people, these are similar to Nietzsche; but Byron is not totally same as Nietzsche, the purpose of his "glower" at the slavish person is with the hope of awakening the slavish people, so "he respects himself and pitiesthe slaves; he suppresses others, but also aids the independence movement of other oppressed nations; he is not afraid of violent winds or even furious waves, but extremely vigilant when riding horses; he loves fighting and worships power, he never forgives enemies, but feel sympathy for the suffering of prisoners. " ( Lu Xun 2005:1:84) 自尊 而怜人之为奴, 制人而援人之独立, 无惧于狂涛而大儆于乘马, 好战崇力, 遇敌无所宽假, 而于 累囚之苦, 有同情焉. Therefore, "Byron favors both the Napoleonic destruction of the world, and George Washington's fight for freedom. He adores the defiant Corsair, and fights a lonely battle with the Greeks for independence. He resists on his own will against oppression. Freedom is on his side, as well as humanity." (Lu Xun 2005:1:81)裴伦既喜拿破仑之毁世界, 亦爱华盛顿之争自由, 既心 仪海贼之横行, 亦孤援希腊之独立, 压制反抗, 兼以一人矣。虽然, 自由在是, 人道亦在是 . When put up againstthe extremists Nietzsche and Tolstoy, Lu Xun prefers Byron, a combination of individualism and humanitarianism. It is also under the influence of Byron that Lu Xun established his personal paradigm in the Chinese social structure as an illuminati and enlightener: he appeared as a devil (or madman, psychotic), fighting against the emperor of heaven on the one hand, and on 
Chenlin, W. (2020). From Scientism to Humanism - the Influence of Modern Western Cultural and Ideological Thoughts on Lu Xun. Advances in Social Science. Research Journal, 7(5) 41-53.

the other hand enlightening the public with the attitude that "feeling merciful for their sufferings, while feeling angry for their recreance.”哀其不幸怒其不争.

This helps us to better understand why Lu Xun show special preference to Byron in the text On the power of Mara poetry, as well as why he has a different evaluating attitude towards Byron and other demon poets. Specifically, in On the power of Mara poetry, Lu Xundevotes two sections to introducing Byron and one section to introducing Shelley, while the other five Mara poets only take half of the length in total. What's more, in the two sections of Byron, Lu Xun doesn't talk about any other Mara poets, while introducing other poets, almost no section doesn't mention Byron - the ones consistent with Byronism are affirmed, while the ones contrary to Byronism are negated, manifested in the introduction of Pushkin. In addition, in the introduction to Shelley, Lu Xun has adapted Shelly according to Byronism, he foregrounds the destructive and combat side of Shelley according to the existing material, ignoring the mild and weak side of him. Therefore, the Shelly in on the power of Mara poetry is not so much like real Shelley, but like Byron and Nietzsche.

In conclusion, during his stay in Japan, Lu Xun established his ideological paradigm and character under the influence of Western culture, (although he adjusted it in the New Cultural Movement). The acceptance and recognition of Western culture not only changed Lu Xun's way of thinking, his ideological character, as well as his way of feeling, but also directly influenced the creation of many his works. All of this laid him an irreplaceable important position in the literary movement at that time. However, it is worth noting that Lu Xun's acceptance of Western culture and ideological trends is based on Nationalism, which is the starting point and internal criteria for Lu Xun, and aimed at national enlightenment and rejuvenation. This is his inner psychological motivation for accepting Scientism and embracing modern humanistic thoughts; his reason of transforming Darwin's theory of evolution into a Nietzsche-style one; this is also the reason why he can mix the contradictory “Tolstoian-Nietzschean Theory”托尼学说 together; and it is also the reason why he chose the pen instead of the scalpel, and turned from Scientism towards Humanism.

\section{Bibliography}

Lu Xun鲁迅, 2005. Lu Xun Quan Ji鲁迅全集

(Complete Works of Lu Xun). 18 vols. Beijing: Renmin wenxuechuban she.

Sun Changxi孙昌熙.1982. “Lu Xun de bijiaowenxue guan ji qi yanzhigudianwenxue de chengjiu” 鲁迅的比较文学 观及其研治古典文学的成就(Lu Xun's View on Comparative Literature and His Achievements in Studying Chinese Classical Literature). Lu Xun Yan Jiu, no.6:20-24

Friedrich Wilhelm Nietzsche. 1986.the Gay Science. Tr. Yu Hongrong. Beijing: Chinese Peace Publishing House, Zhou, Guoping周国平. 1986. Nicai: zaishiji de zhuanzhedianshang尼采: 在世纪的转折点上 (Nietzsche: at the turning point of the century). Shanghai: shanghai renminchuban she.

Jaroslav Průšek.1987. Subjectivism and Individualism in Modern Chinese Literature. Tr. Li Yanqiao. Pu ShikeZhongguowenxuelunwen ji普实克中国现代文学论文(A collection of prusek's analysis on Chinese Modern Literature Collection). Changsha: Hunan Literature and Art publishing House.

Cheung, Chiu-Yee. Lu Xun: The Chinese 'Gentle' Nietzsche. Frankfurt, et al.: Peter Lang, 2001.

Pusey, James Reeves. Lu Xun and Evolution. Albany: SUNY Press, 1998.

Liu, Lydia. "Life as Form: How Biomimesis Encountered Buddhism in Lu Xun." Journal of Asian Studies 68, 1 (Feb. 2009): 21-54. 
Advances in Social Sciences Research Journal (ASSRJ)

Vol.7, Issue 5, Apr-2020

Kwok, D. W. Y. Scientism in Chinese Thought, 1900-1950. Yale University Press, 1965.

Elman, Benjamin. On Their Own Terms: Science in China, 1550-1900. Harvard University Press, 200 